\title{
O DESAFIO DO ENSINO DA LITERATURA: O PAPEL DA MÚSICA COMO ESTRATÉGIA PEDAGÓGICA.
}

\author{
Marilani Soares Vanalli ${ }^{1}$, André Luís de Oliveira Siribeli ${ }^{2}$, Elaine Cristina Paris ${ }^{3}$, Valéria Novaes Domingues ${ }^{4}$ \\ ${ }^{1}$ Mestre em Letras pela Universidade Estadual Paulista - UNESP. Docente da Universidade do Oeste Paulista - \\ UNOESTE, Presidente Prudente, SP. E-mail: marilani@unoeste.br \\ ${ }^{2}$ Graduando em Letras pela Universidade do Oeste Paulista - UNOESTE, Presidente Prudente, SP. E-mail: \\ andresiribeli@hotmail.com \\ ${ }^{3}$ Graduanda em Letras pela Universidade do Oeste Paulista - UNOESTE, Presidente Prudente, SP. E-mail: \\ elaine.paris@hotmail.com \\ ${ }^{4}$ Graduanda em Letras pela Universidade do Oeste Paulista - UNOESTE, Presidente Prudente, SP. E-mail: \\ val lill@yahoo.com.br
}

\section{RESUMO}

Esse artigo objetiva revelar a literatura como fonte de prazer ao leitor, e, que além da leitura e análise teórico/semântica dos textos de literatura, quando em união com a música, podem potencializar o ensino daquela, visando torná-lo mais significativo. Para tanto, é necessário contextualizar o ensino de literatura e discutir a importância da música no contexto escolar; apresentando propostas para este ensino dialogado e intertextual. Foram utilizados os textos poéticos "O velho do Restelo " - Luís Vaz de Camões, " Fala do Velho do Restelo ao astronauta" - José Saramago "e " Astronauta" - Gabriel Pensador. Realizou-se uma pesquisa de caráter qualitativo, com um apoio bibliográfico elaborado a partir de materiais já publicados. Os estilos literários e a canção popular tratam de composições diferentes, mas possuidores de uma relação íntima, quase complementar. A intertextualidade entre as poesias e a letra da música ficam confirmadas, numa condição paródica. Conclui-se que, pode ser muito fácil gostar de música e, dificilmente, será encontrado alguém que não aprecie uma canção. Depois destes estudos mais verticalizados, pode-se afirmar que a literatura $\mathrm{x}$ música trazem um bem-estar inestimável, despertando a sensibilidade e criatividade dos alunos. Em sala de aula, esta aproximação pode ser muito benéfica e conduzir à aprendizagem de forma mais sensível, fluida e eficaz.

Palavras-chave: Literatura. Ensino. Música. Estratégia pedagógica.

\section{THE CHALLENGE OF LITERATURE EDUCATION: THE ROLE OF MUSIC AS A PEDAGOGICAL STRATEGY.}

\begin{abstract}
This article aims to reveal literature as a source of pleasure to the reader, and that in addition to reading and theoretical / semantic analysis of literature texts, when in conjunction with music, can potentiate the teaching of it, in order to make it more meaningful. Therefore, it is necessary to contextualize literature teaching and discuss the importance of music in the school context; presenting proposals for this dialogue and intertextual teaching. The poetic texts "The old man of Restelo" - Luís Vaz de Camões, "Talking of the Old Man of Restelo to the astronaut" - José Saramago "and" Astronaut "- Gabriel Pensador. A qualitative research was carried out, with bibliographical support elaborated from already published materials. The literary styles and the popular song deal with different compositions, but possessing an intimate, almost complementary relation. The intertextuality between the poems and the lyrics of the music are confirmed, in a parody condition. It turns out that it can be very easy to like music and it will be difficult to find someone who does not enjoy a song. After these more vertical studies, it can be affirmed that the literature $x$ music brings an inestimable wellbeing, awakening the sensitivity and creativity of the students. In the classroom, this approach can be very beneficial and lead to learning in a more sensitive, fluid and effective way.
\end{abstract}

Keywords: Literature. Teaching. Music. Pedagogical strategy. 


\section{INTRODUÇÃO}

O ensino de literatura não tem se desenvolvido de forma satisfatória nas escolas públicas brasileiras. Vários são os fatores que contribuem para que isto não aconteça, dentre os quais, destaca-se a insuficiente quantidade de leitura entre os alunos da rede pública de ensino, principalmente, no Ensino Médio.

Para superar esse problema, acredita-se que a música possa ser utilizada como instrumento de fruição e promoção do ensino da literatura. Tais recursos podem encontrar-se relacionados a um poema famoso de Camões ' $O$ velho do Restelo' em Os Lusíadas; bem como no de José Saramago em "Fala do velho do restelo ao astronauta", estabelecendo, estes dois anteriores, um diálogo interessante com a canção "Astronauta", de Gabriel, O Pensador, método didático intertextual que favorece um maior aprendizado em sala de aula.

Acredita-se que a literatura auxiliada pela música, ambas consideradas como arte em áreas diferenciadas, mas que, em comunhão, possam maximizar o interesse do aprendizado de alunos que contextualmente, hoje, façam parte do Ensino Médio. Assim sendo, é possível que pela perspectiva da Intertextualidade esse objetivo seja alcançado com o êxito esperado. 0 eixo estrutural verticalizado nesta Iniciação Científica tem como base fundamental a aprendizagem em sala de aula e o despertar da sensibilidade do ser humano de forma integral.

Percebe-se que a literatura e música são instrumentos facilitadores do processo do ensino-aprendizagem. Portanto, é importante criar situações onde se possam desenvolver atividades que explorem a imaginação, emoção e habilidades, de uma forma prazerosa e significativa.

A música, por sua vez, quando bem trabalhada pelo professor no despertar da sensibilidade; orientar para o encadeamento das sonoridades; a percepção da letra, e muitos outros aspectos possíveis, desenvolve o raciocínio e a criatividade. A literatura, destacase com força pelo encantamento despertado por muitas obras; a junção de alguns fatores com uma boa história; um enredo de tirar o fôlego e personagens marcantes. Estes e outros são os motivos que movem essa paixão pela literatura ao encontrarmos toda essa variedade de vida que pulsa em cada frase de um romance, conto ou poesia. Desta maneira, buscamos encontrar sentido para nossa existência pessoal e profissional.

Devido à falta de interesse, déficit de atenção e cultura dos alunos no século XXI, a música aliada à literatura pode amenizar essas deficiências encontradas no ensino, superando dificuldades de fala, linguagem e interpretação além de contribuir para o aumento do nível cognitivo, reduzindo a ansiedade e promovendo vínculos.

Uma vez que a literatura é uma forma para conhecermos nossa história, é essencial e de suma importância trazê-la para nossa vida, convívio social e interação humana. Sendo assim, esta, quando aliada a música, torna-se um meio mais fácil e autêntico de entendimento.

Pensando desta maneira, no contexto educacional que necessita de novas metodologias, pretendemos apresentar uma proposta de diálogo entre as duas áreas: literatura e música para que ambas, auxiliem-se mutuamente na direção de um ensino e de uma aprendizagem melhor. Os textos poéticos e o musical indicados na Introdução é que serão os alvos de nossa pesquisa.

\section{MÉTODOS}

Realizou-se uma pesquisa de caráter qualitativo, com um apoio bibliográfico elaborado a partir de materiais já publicados como, por exemplo, artigos científicos e livros de autores da área dos quais dominam o tema em questão. Os mesmos forneceram subsídios teóricos bastante relevantes.

Pesquisa qualitativa é multimetodológica quanto ao seu foco, envolvendo abordagens interpretativas e naturalísticas dos assuntos. Isto significa que o pesquisador qualitativo estuda coisas em seu ambiente natural, tentando dar sentido ou interpretar os fenômenos, segundo o significado que as pessoas the atribuem.

Segundo Fonseca, (2002, p. 32) nos diz que:

A pesquisa bibliográfica é
feita a partir do
levantamento de
referências teóricas já
analisadas, e publicadas
por meios escritos e
eletrônicos, como livros,
artigos científicos,
páginas de web sites.
Qualquer trabalho
científico inicia-se com
uma pesquisa


bibliográfica, que permite ao pesquisador conhecer o que já se estudou sobre o assunto. Existem, porém pesquisas científicas que se baseiam unicamente na pesquisa bibliográfica, procurando referências teóricas publicadas com o objetivo de recolher informações ou conhecimentos prévios sobre o problema a respeito do qual se procura a resposta.

Após o levantamento bibliográfico e o fichamento das obras, realizamos a análise do diálogo existente entre as obras de José Saramago, Luís Vaz de Camões e Gabriel O Pensador.

\section{RESULTADOS}

Um texto dialoga com outros textos, mas também é referência de seu tempo, de uma sociedade, crenças, de problemas sociais e essas relações de intertextualidade, demonstram um legado que atravessa gerações. A música e literatura evidenciam também a evolução que tais obras podem sofrer com o passar do tempo. Quando uma música como "Astronauta" assume o compromisso de conscientização social, existe uma relação entre literatura, música e sociedade, e é o público que proporciona esta evolução.

A utilização do lúdico na educação tem como objetivo tornar o processo de ensinoaprendizagem mais atrativo para 0 aluno, conciliando aspectos culturais com o conhecimento. Diante de todas as dificuldades encontradas em sala de aula, principalmente com relação a leitura, faz-se necessário que o professor crie condições que leve os alunos a gostarem daquilo que estão fazendo, criar condições e meios motivadores para despertar interesse e desenvolver um processo de ensino que traga resultados.

O objetivo dessa pesquisa foi apresentar um estudo sobre o diálogo e comunhão da literatura e da música em uma proposta que incentive a leitura nas escolas públicas brasileiras. Foram analisados os textos poéticos "O Velho do Restelo" de Luís Vaz de Camões, "Fala do Velho do Restelo ao Astronauta" de
José Saramago e "Astronauta" de Gabriel Pensador.

Depois destes estudos mais verticalizados, podemos afirmar que a literatura x música nos trazem um bem-estar inestimável, despertando a sensibilidade e criatividade dos alunos. Em sala de aula, esta aproximação pode ser muito benéfica e conduzir à aprendizagem de forma mais sensível, fluida e eficaz.

\section{DISCUSSÃO}

A literatura tem a função humanizadora, ou seja, a capacidade de confirmar a humanidade do homem. Nela, encontra-se emoção, experiência, significados, histórias, encantamentos, sonhos e vida. Por causa da linguagem é possível criar mundos fictícios que em muitos aspectos são semelhantes e relacionados ao mundo da vida em que vivemos, tornando-a verossímil.

Uma das razões mais importantes para o nosso envolvimento emocional na literatura é a nossa empatia com a leitura; com o prazer que ela nos desperta e a nossa constante imaginação e hipótese de possível transmitir aos alunos, a paixão que por ela sentimos, seduzindo-os para leituras de fato.

As dificuldades para o ensino da literatura são muitas, a falta de interesse é uma delas e o reflexo desse descaso é possível ver e sentir nas escolas onde os alunos sentem muita dificuldade para elaborar uma redação, ou qualquer outra atividade que envolva a escrita.

O dicionário Houaiss apresenta a definição de música como uma combinação harmoniosa e expressiva de sons; a arte de se exprimir por meio de sons, seguindo regras variáveis conforme a época, a civilização etc. A música imita sentimentos que surgem através da nossa interação com os outros no mundo. Em um sentido mais abrangente, podemos definir a música como a arte de amar, sentir, ver, expressar e de se comunicar por meios das diferentes sonoridades transmitidas, pela voz ou por um determinado instrumento.

Vários recursos já foram implantados no sistema educacional para contribuir um ensino de qualidade, a música diante de tantos significados pode também ser uma ferramenta para o aprendizado, pois permite auxiliar na memória e no raciocínio.

$\mathrm{Na}$ concepção de Nascimento (2012, p.19). 
A arte, como elemento motivacional, alimenta e é alimentada pelo lúdico, pela imaginação daquele que dela usufrui. Sendo assim, o indivíduo ao expressar sua arte pelas letras das músicas, lança mão e externa suas concepções acerca da interpretação que faz diante de determinado aspecto do mundo em que vive. Por outro lado, o ouvinte pode apoderarse delas ou até mesmo refutá-las, haja vista que o mais importante, seja identificar a qual contexto aquelas condições se referem para que sejam emanadas outras discussões dentro e fora do campo das ciências.

A dinâmica de funcionamento de uma sociedade industrial impõe outra configuração de valores, em que o conhecimento técnico científico acaba se sobrepondo ao conhecimento de natureza artística, como é o caso da música. Pode-se observar que o campo das formas musicais é verdadeiramente fértil e de fácil assimilação, portanto, útil para o trabalho do professor que deseja renovar, dinamizar e buscar maior eficiência de aprendizado em seu modo de explicar a matéria.

Iniciando a análise, "O Velho do Restelo", aparece no canto IV, estâncias 94 a 104, de Os Lusíadas, de Luís Vaz de Camões, quando a frota de Vasco da Gama se prepara para novas conquistas além-mar, entre a população que comparece na praia para chorar a partida dos navegadores, individualiza-se a figura de um velho. Ele apresenta uma opinião adversa ao projeto expansionista de seus compatriotas, numa perspectiva pessimista, ao enumerar as consequências desse engano, nomeadamente o desamparo e a inquietação em que deixam familiares e o "desprezo da vida" que faz ir ao encontro de desastres, perigos e morte.

Segundo Alfredo Bosi (1977 p. 37-46):

O episódio do Velho do Restelo é o anticlímax da epopeia, a voz do Velho é um contraponto, pois a viagem trará muitas consequências ao povo lusitano, é uma crítica direta à cobiça humana em busca das especiarias nas Índias e novos territórios.

Bosi (1977) tem razão ao afirmar que a voz do Velho é um contraponto, uma vez que o ponto de vista que ele adota está na contramão do que a maioria pensa e deseja. Para elucidar melhor tais considerações, apresentar-se- do Canto IV-94 ao 97, como forma de explicitar a análise executada.

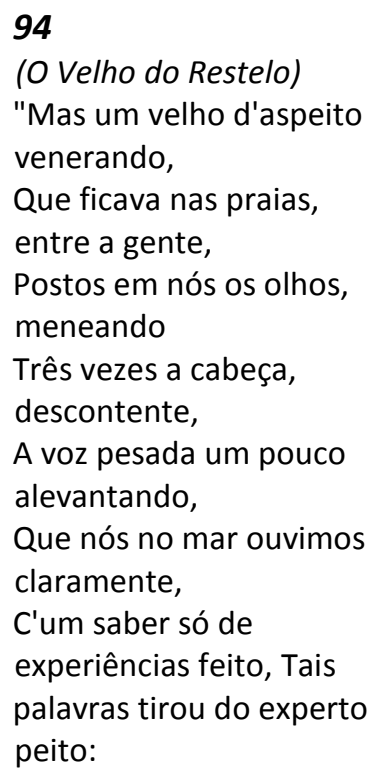

$\mathrm{Na}$ estrofe acima, o personagem é apresentado de forma respeitosa, tais atributos como 'venerável' e 'experiente' são direcionados ao velho. Um velho sábio que representa a população que sofre com o sistema político e econômico. Logo adiante, o velho condena a aventura dos portugueses, e ao longo das estrofes 95 até a 104 constitui o mais importante desvio da épica Camoniana.

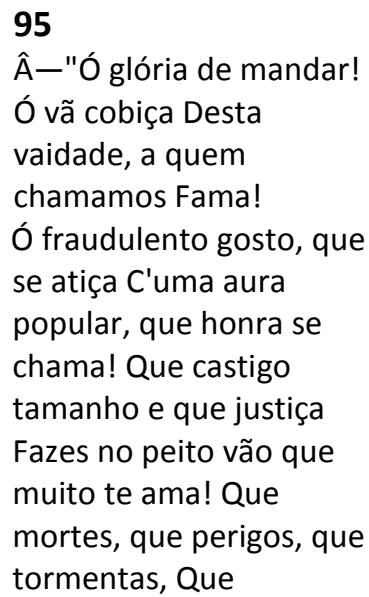


crueldades neles experimentas! (1995)

Neste excerto, o discurso é intenso e regado de austeridade, uma vez que a linguagem é construída pelo tom da agressividade. $O$ ancião é contra o idealismo imperialista da exploração do Oriente, e em contraposição é o idealismo que a epopeia enaltece. As críticas são envergadamente endurecidas, mas denunciam a ânsia de um comportamento regido pelo capitalismo exagerado: a necessidade de novas conquistas, como se pode perceber em (1995):

\section{6}

Â- "Dura inquietação d'alma e da vida, Fonte de desamparos e adultérios, Sagaz consumidora conhecida De fazendas, de reinos e de impérios:

Chamam-te ilustre, chamam-te subida, Sendo dina de infames vitupérios;

Chamam-te Fama e Glória soberana,

Nomes com quem se o povo néscio engana!

\section{7}

Â-"A que novos desastres determinas $\mathrm{De}$ levar estes reinos e esta gente? Que perigos, que mortes lhe destinas

Debaixo dalgum nome preeminente? Que promessas de reinos, e de minas D'ouro, que the farás tão facilmente?

Que famas lhe prometerás? que histórias?

Que triunfos, que palmas, que vitórias? (1995)

Na estrofe 96, o discurso é reflexivo e edificante. $\mathrm{O}$ velho fala da mediocridade espiritual; da ilusão dos valores fúteis (fama e glória), a porta para a corrupção e desunião da ordem social. O questionamento inoportuno de tal conduta é lançado na estrofe 97 , ao qual indaga até onde os portugueses são capazes de arriscar o destino dos reinos e nações. O substantivo reino empregado no plural pode significar tanto a coroa portuguesa, como aqueles reinos que são alcançados e sujeitos à exploração e escravidão.

Destacam-se nestas estrofes, a profusão de fonemas oclusivos (/d/ / t/ /q/ /p/) revelando a força de um efeito vibrante, ressonante. É importante frisar, na estrofe 97, o emprego do sinal de pontuação 'interrogação' em todos os versos, carrega semanticamente a conotação do caráter de julgamento e proibição.

Nesse primeiro momento, o eu lírico condena o envolvimento do país na aventura dos descobrimentos, à qual se refere de forma negativa como em "A que novos desastres determinas, de levar estes reinos e esta gente" e denuncia a condição ilusória das justificações de caráter heroico que foram apresentadas para esse empreendimento, conforme se verifica em "Que promessas de reinos, e de minas, D'ouro, que Ihe farás tão facilmente". (1995)

É possível notar uma magnífica intertextualidade do texto de Camões com as fontes clássicas do antigo testamento do livro de Gênesis. Este referido autor português foi buscar inspiração na tragédia do homem primogênito. 0 insano que se deixou levar pela mulher e perdeu o jardim da prosperidade que the servia de morada. $O$ pecado e a desobediência levaram o casal à deportação do paraíso e ficaram apenas as lembranças amargas.

O desabafo percebido no eu lírico evoca o pecado de Adão e Eva, e automaticamente compara que os lusitanos terão o mesmo destino: irão para a nau de amargura e tragédia.

Em seguida, os excertos das estrofes 98 e 99 (1995), como assim se apresentam:

98

Â- "Mas ó tu, geração

daquele insano,

Cujo pecado e

desobediência,

Não somente do reino

soberano

Te pôs neste desterro e triste ausência,

Mas inda doutro estado

mais que humano

Da quieta e da simples

inocência,

Idade d'ouro, tanto te

privou,

Que na de ferro e d'armas te deitou:

99

Â- "Já que nesta gostosa vaidade 
Tanto enlevas a leve

fantasia,

Já que à bruta crueza e

feridade

Puseste nome esforço e

valentia,

Já que prezas em tanta

quantidades $\mathrm{O}$ desprezo

da vida, que devia De ser

sempre estimada, pois

que já Temeu tanto

perdê-la quem a dá:

(1995)

$\mathrm{Na}$ estrofe 98, os portugueses representam o homem universal, aqueles que são capazes de decidir o destino da nação; que carregam as características viciosas da natureza humana, ambição, prepotência e orgulho. O velho alerta para os perigos da soberba ao ponto de confundir a valentia com brutalidade e ferocidade, e ainda enfatiza a importância de valorizar a vida, pois só lhe dá o devido valor, quem já temeu perdê-la.

Dando continuidade, temos a estrofe 100 que traz as seguintes abordagens:

$$
\begin{aligned}
& 100 \\
& \text { Â- "Não tens junto } \\
& \text { contigo o Ismaelita, Com } \\
& \text { quem sempre terás } \\
& \text { guerras sobejas? Não } \\
& \text { segue ele do Arábio a lei } \\
& \text { maldita, Se tu pela de } \\
& \text { Cristo só pelejas? Não } \\
& \text { tem cidades mil, terra } \\
& \text { infinita, Se terras e } \\
& \text { riqueza mais desejas? } \\
& \text { Não é ele por armas } \\
& \text { esforçado, Se queres por } \\
& \text { vitórias ser louvado? } \\
& \text { (1995) }
\end{aligned}
$$

Neste excerto, o velho ainda diz que os portugueses deveriam lutar com ismaelita que está à porta, em vez de buscar inimigo distante, as razões que justificariam a luta com os ismaelitas é o fato deles não seguirem a Lei de Cristo e possuírem riquezas e terras.

Seguindo para a análise da estrofe 101, temos que:

\section{1}

$\hat{A}$ - "Deixas criar às portas o inimigo, Por ires buscar outro de tão longe, Por quem se despovoe o Reino antigo, Se enfraqueça e se vá deitando a longe? Buscas

o incerto e incógnito

perigo

Por que a fama te exalte e te lisonje, Chamando-te senhor, com larga cópia, Da Índia, Pérsia, Arábia e de Etiópia? (1995)

Neste ponto a crítica do velho torna-se intrínseca contra a empresa oriental, não somente a viagem de Vasco da Gama, mas contra todas as formas de conquista e exploração no Oriente onde a manutenção está levando o reinado ao declínio.

As estrofes finais guardam vastas $e$ apuradas análises da teoria da literatura, como se perceberá a seguir:

102

Â- "Ó maldito o primeiro que no mundo Nas ondas velas pôs em seco lenho, Dino da eterna pena do profundo, Se é justa a justa lei, que sigo e tenho!

Nunca juízo algum alto e profundo, Nem cítara sonora, ou vivo engenho, Te dê por isso fama nem memória, Mas contigo se acabe o nome e glória.

103

Â- "Trouxe o filho de Jápeto do Céu O fogo que ajuntou ao peito humano, Fogo que o mundo em armas acendeu Em mortes, em desonras (grande engano). Quanto melhor nos fora, Prometeu, E quanto para o mundo menos dano, Que a tua estátua ilustre não tivera Fogo de altos desejos, que a movera!

\section{4}

Â- "Não cometera o moço miserando O carro alto do pai, nem o ar vazio $O$ grande Arquiteto co'o filho, dando Um, nome ao mar, e o outro, fama ao rio. 
Nenhum cometimento alto e nefando, Por fogo, ferro, água, calma e frio, Deixa intentado a humana geração. Mísera sorte, estranha condição!" (1995)

Na estância 102, o poeta recorda figuras míticas como em "Ó maldito, o primeiro que, no mundo, / Nas ondas velas pôs em seco lenho", (1995) em desapreço ao desejo dos portugueses pelas conquistas e pela glória, que cada vez mais vão longe a suas navegações, deixando sem defesa a própria pátria, e desabitando o reino que tem o povo não tem juízo e toma estas decisões irracionais para buscarem um imaginário, condena o inventor da navegação à vela, que constitui a ideia principal do discurso do Velho do Restelo.

Dando continuidade, na estância 103, "Trouxe o filho de Jápeto do céu O / Fogo que o mundo em armas acendeu" (1995), faz referência a Prometeu e ícaro, que segundo a mitologia grega, teria criado a espécie humana, e roubado o fogo sagrado do Olimpo e com ele fez a estátua ilustre - uma estátua de barro - dando assim, origem ao homem, onde os mesmos foram severamente castigados, em conclusão esse comportamento humano será conduzido à uma dura desgraça.

Chegando à última estância, a 104, no verso "Não cometera o moço miserando, / O carro alto do pai, nem o ar vazio"(1995), referência a Phaeton que roubou o carro do sol, e o verso

"O grande Arquiteto co'o filho", menção a Dédalo, construtor do labirinto de Creta, que preso com seu filho ícaro neste labirinto, construiu asas artificiais com as penas dos pássaros que sobrevoavam o local, e voou para fora do mesmo, mas as asas que eram coladas com cera de abelha derreteram e ícaro caiu ao mar para desespero de Dédalo, que chorou a morte do filho por toda a sua vida. Estes símbolos são casos paradigmáticos de ambição com consequências dramáticas, e, o autor, evoca o passado para censurar a ambição humana.

Continuando a análise e explorando a estrutura formal, percebe-se que as estrofes se constituem em oitavas, tendo, portanto, oito versos; a rima é cruzada nos seis primeiros versos $(A B A B A B)$ e emparelhada $(C C)$ nos dois últimos, revelando então a estrutura em cada estrofe de ( $A B A B A B C C)$.

Cada verso quando escandido é constituído por dez sílabas métricas (decassílabos), em sua maioria chamada heroicos (quando a tonicidade recai nas sextas e décimas sílabas). A linguagem arcaica pode inicialmente - afastar o leitor da atualidade, mas as principais dificuldades encontradas na leitura são: o léxico antigo utilizado; a sintaxe truncada e o grande número de informações mitológicas e históricas.

Segundo Cândido (2006, p. 83) "a literatura é, pois, um sistema vivo de obras, agindo uma sobre as outras e sobre os leitores e só vive na medida em que estes a vivem, decifrando-a e aceitando-a; deformando-a". Para o autor, há uma relação de dependência entre obra, autor e público. A obra é mediadora entre o autor e o público, e o público é o mediador entre o autor e a obra, pois o autor só pode ter plena consciência da obra quando ela lhe é mostrada por meio da reação de terceiros, sendo o público a condição para o autor conhecer a si próprio. O público tem o papel de ponto de referência para o autor, já que a reação do outro é necessária para a autoconsciência. Esse sistema seria a articulação dos elementos que constituem a literatura, autores formam um conjunto que permitem nosso relacionamento, definindo "uma vida literária", públicos amplos ou restritos, capazes de ler ou ouvir as obras, permitindo com que elas circulem.

O sentido do discurso atribuído ao Velho parece bastante claro, já que o episódio coloca alguns problemas quanto ao pensamento do poeta relativamente à questão tratada. Faz um discurso veemente, condenando aquela aventura insana, que segundo ele, pela cobiça, o desejo de riquezas, poder, fama, para ir enfrentar perigos desconhecidos, os portugueses abandonavam os perigos urgentes de seu país.

o velho representa uma opinião conservadora, e várias pessoas daquela época pensavam da mesma maneira, assim como se pode fazer a relação como muitos pensam hoje, no que diz respeito a assuntos semelhantes (como a conquista espacial ou a manipulação genética, por exemplo).

Na época, havia uma corrente de opinião em Portugal que condenava a política ultramarina do país com o abandono das conquistas africanas. Entende-se que o Velho do Restelo não seja propriamente uma voz 
discordante. $O$ poeta concede um lugar em seu poema representando nele, os rumores do povo ou o ponto de vista de um partido adversário da empresa que o poeta se punha a celebrar.

Os Lusíadas, poema épico de Portugal, escrito em 1572 pelo poeta Luís de Camões, canta a viagem de Vasco da Gama à Índia e as aventuras dos portugueses.

Biograficamente falando, Luís Vaz de Camões nasceu entre 1517 e 1525, presume-se que ganha erudição em Coimbra. Fidalgo pobre, mas bem relacionado, frequenta a corte lisboeta com sucesso entre as damas.

O caráter aventureiro e tumultuoso abreIhe a porta de várias prisões. Após um período encarcerado, parte supostamente desterrado pelo Rei, para um exílio de 17 anos, onde completa a maior parte do poema épico.

Numa era em que Portugal e Espanha são divididos entre dois mundos e que o Latim é a língua oficial erudita, Os Lusíadas, ergue também o Português ao nível dos seus efeitos marítimos.

A conquista ultramarina foi um fator significativo para o ressurgimento da epopeia em Portugal, cabendo a Camões a missão de fazer o poema épico que narrou os feitos lusitanos. Desta forma nasceu Os Lusíadas, que teve como objetivo principal narrar a expansão políticoreligiosa, pois Portugal estava no auge do seu império, conquistado com a coragem de sua gente, que pioneiramente desbravou o mar desconhecido.

Segundo Massaud Moisés (1997, p. 5360) nesse período "a prosa não tinha muita importância estética, a poesia era tida, como mais nobre e como não havia nada mais nobre que a expansão ultramarina, o poema teria que ser escrito à altura dos feitos portugueses".

A figura do Velho representa a corrente de opinião que via com desagrado o envolvimento de Portugal nos Descobrimentos, representa a voz da razão num momento de euforia e deslumbramento, a voz da experiência perante a irreverência.

O episódio pode ser entendido não só como um reflexo social, mas também como uma manifestação do espírito humanista, favorável à paz e tranquilidade, contrariando o espírito guerreiro da Idade Média.

Prosseguindo com as biografias, o autor José Saramago nasceu em Portugal em 1922, é considerado um dos maiores expoentes da literatura contemporânea, recebeu importantes prêmios como o Nobel de Literatura e Camões. Foi um verdadeiro autodidata e conseguiu absorver uma vasta cultura da literatura, filosofia e história. Consolidou-se como um inestimável escritor em prosa e poesia com destaque para obras como "Os Poemas Possíveis" (1966), "Provavelmente Alegria" (1970) e "Memorial do Convento" (1980). O trabalho de José Saramago é extenso e engloba diversas áreas da literatura como crônicas, teatros, romances traduções e contos.

O poema "Fala do velho do restelo ao astronauta", faz parte da obra "Os Poemas Possíveis" de 1966, composta por 147 poemas, foi construída em um regime político ditatorial de Salazar, uma das mais longas ditaduras do século XX, Portugal viveu com censuras, repressões e autoritarismo até abril de 1974.

$\mathrm{Na}$ epopeia Camoniana, encontra-se o discurso do Velho do Restelo, onde aparecem com larga nitidez a oposição às conquistas dos portugueses. A fala do personagem gerou muitas discussões, em relação aos motivos que levaram Camões a introduzir uma voz contra a bravura e ousadia dos lusitanos e ideologia da política ultramarina de Portugal.

Estudiosos apontam que o discurso pode ter dupla interpretação: a primeira como a voz da sabedoria; e a segunda, como a da classe conservadora.

O episódio do Velho do Restelo é representado em novos contextos literários, pela sua ambiguidade e contrariedade, e, oferece leituras que questionam a maior conquista dos portugueses.

Na construção Saramaguiana "Fala do Velho do Restelo ao Astronauta" (1966), o poema reflete os problemas que Portugal convivia com a ditadura, potencializado por um discurso tenso e requintado com uma ironia ácida dirigida à sociedade, fazendo alusão à corrida espacial e à guerra do Vietnã. Nota-se o estilo próprio do autor e suas reflexões sobre os aspectos sociais relacionados à evolução tecnológica e humana. É uma escrita intertextual e dialógica ao poema Camoniano, uma vez que cada um representa através da voz nas textualidades, a que contexto cada uma delas pertence, não deixando de estabelecerem diálogo entre elas, embora pertençam a contextos cronologicamente distantes.

Para Candido (2006, p.83)

a literatura é, pois um sistema vivo de obras, 
agindo umas sobre as outras e sobre os leitores, e só vive na medida em que estes a vivem, decifrando-a, aceitandoa, deformando-a [...] são dois termos que atuam um sobre o outro, e aos quais se junta o autor, termo inicial desse processo de circulação literária, para configurar a realidade da literatura atuando no tempo.

Candido tem razão ao afirmar que a literatura é um sistema vivo de obras e que elas estabeleçam um diálogo sincrônico e diacrônico, em muitos casos, pois se convertem em espaços de arte de criação literária e representem o contexto do qual fazem parte.

O escritor José Saramago recria Camões usando toda sua sátira para expressar sua desaprovação com o homem. A fala do Velho do Restelo ao Astronauta é um exemplo que a arte é atemporal e se adapta as mudanças.

Nos excertos a seguir, cada escritor define sua forma de poesia, Saramago tecendo as palavras como num jogo musical, convida o leitor a entrar em um universo misterioso, cheio de incógnitas e extremamente mágico. O excerto a seguir de Saramago (1977) é exemplo deste ambiente de criação:

Essas coisas que escrevo, se alguma vez as li antes, estarei agora imitando-as, mas não de propósito o que faço. Se nunca as li, estou-as inventando, e se pelo contrário li, então é porque aprendera e tenho o direito de me servir delas como se minhas fossem e inventadas agora mesmo.

O espaço da criação, fruição, denúncia e sensibilidade é a ambientação literária nascidas ou do imaginário do autor, ou recriadas e reinventadas de obras já lidas anteriormente. 0 fragmento a seguir, é o espelhamento da denúncia que o eu lírico é incapaz de calar "Aqui, na Terra, a fome continua, /A miséria, o luto, $e$ outra vez a fome". (2014) No fragmento apresentado do texto poético, a voz do velho do Restelo ressurge, porém, evidencia problemas universais como a fome e a miséria não se restringem apenas as angústias do povo lusitano. Ruptura e transgressão parecem ser traços originais de Saramago pela sua narrativa autêntica, sempre antiga, sempre atual, uma forma de reflexão sobre o passado e presente, a estratégia usada é a de um deslocamento do tempo pelo fato da linguagem ser um processo temporal.

De acordo com Candido (2006, p. 53)

A grandeza de uma literatura ou de uma obra depende da sua relativa intemporalidade e universalidade, e estas dependem por sua vez da função total que é capaz de exercer, desligando-se dos fatores que a prendem a um momento determinado e a um determinado lugar.

A atemporalidade na obra Saramaguiana permite um encontro com o passado de Camões e um questionamento do presente de Saramago, ou seja, o discurso do velho do Restelo atravessa gerações e possibilita discussões sobre a mesma temática na "Fala do velho do restelo ao astronauta", de José Saramago (2014, p. 84)

Acendemos cigarros em fogos de napalme $E$ dizemos amor sem saber o que seja. Mas fizemos de ti a prova da riqueza, $\mathrm{E}$ também da pobreza, e da fome outra vez. $E$ pusemos em ti sei lá bem que desejo De mais alto que nós, e melhor e mais puro.

Neste fragmento apresentado, percebese que os atos textuais consistem em um conjunto de significados e significantes, marcados pela precisão e sensibilidade, uma vez que o escritor revela-se atuando a consciência e o gesto criativo, e pondera sobre a miséria e prepotência humana. O eu lírico parece deixar nítida a decepção e perplexidade com o ser humano, mesmo com a evolução tecnológica e espacial, expressa um desapontamento com o homem que se transformou em um monstro egoísta e ambicioso incapaz de ajudar as pessoas em situações de miséria. A seguir, o fragmento pode revelar a crítica explicitada ao longo dos 
versos, como espasmos de dor sentidos pela voz que se ergue do texto, Saramago (2014, p. 84)

No jornal, de olhos tensos, soletramos As vertigens do espaço e maravilhas: Oceanos salgados que circundam Ilhas mortas de sede, onde não chove.

A crítica é direcionada a civilização moderna, o poema é alicerçado em versos engajados que se apoia em uma retórica redentorista ou social participativa, característica de uma linhagem de poesia neorrealista integrando-se a dados estéticos e temáticos alheios à corrente neorrealista em geral.

O escritor José Saramago (2014, p. 84) cria um neo-Velho do Restelo, e expressa de modo apático as conquistas científicas e tecnológicas.

\author{
Mas o mundo, \\ astronauta, é boa mesa \\ Onde come, brincando, só \\ a fome, \\ Só a fome, astronauta, só \\ a fome, \\ E são brinquedos as \\ bombas de napalme.
}

Saramago retrata uma época de transformações, mas nada ainda para ser celebrado, pois a fome e as guerras permanecem em demasia, o progresso da humanidade resultou mais em perdas que em ganhos. 0 apego à forma humana e aos discursos humanistas são reflexos das inquietações Saramaguiana.

Cândido (2006, p. 52) esclarece que:

O artista quer atingir
determinado fim; o
auditor ou leitor deseja
que ele lhe mostre
determinado aspecto da
realidade. Todo este lado
voluntário da criação e da
recepção da obra
concorre para uma
função específica, menos
importante que as outras
duas e frequentemente
englobada nelas, e que se
poderia chamar de
função ideológica [...] o
autor dirá, por exemplo,
que tencionou mostrar

como a vida é enganadora e como a virtude é uma questão de aparência.

A partir da afirmação de Cândido, é correto afirmar que Saramago faz um contraste entre as conquistas do homem e seu desdém com seus semelhantes. O escritor usa a poesia social e centra a temática na denúncia dos problemas relacionados com a evolução e a miséria.

Momentaneamente deixando a interpretação da poesia de Saramago, e dando sequência com as demais análises é interessante se aprofundar na canção "Astronauta", composta pelo rapper Gabriel, 'O Pensador' com participação do cantor Lulu Santos.

"Gabriel O Pensador" é o nome artístico de Gabriel Contino, nascido no Rio de Janeiro em 4 de março de 1974. Posiciona-se como um dos maiores nomes do rap brasileiro com sua participação em um universo marcado por músicos jamaicanos e negros imigrantes nos EUA. Neste contexto, diferencia-se de músicos do rap por ser branco e de classe média. Gabriel O Pensador (2015) assim se manifesta:

Minha relação com a música tem a ver com a letra acima de tudo. Sempre gostei de prestar atenção nela, desde quando comecei a ouvir o que os pais ouviam, a MPB, até depois, na préadolescência, ouvindo rock brasileiro- Legião, Titãs, Blitz, Ultraje a Rigor, Camisa de Vênus. Escutava coisas em inglês sem saber o que significavam e gostava. Mas fui aprender e me apaixonar quando comecei a entender as letras de Bob Marley, Beastie Boys e Run DMC. Isso reforçou minha paixão e decidi fazer música também.

Em 1992, Gabriel aparece no cenário musical quando ainda era estudante de Comunicação Social na Pontifícia Universidade Católica do Rio de Janeiro, com a música "Tô feliz" (Matei o Presidente). A letra da música fala 
de Fernando Collor de Mello, que tinha acabado de renunciar à presidência do país, frente a um processo de impeachment. Sua mãe, a jornalista Belisa Ribeiro havia sido assessora de Collor.

Por causa do sucesso da música foi contratado pela Sony Music, e em 1993 lançou seu primeiro disco "Gabriel O Pensador", que ganhou as rádios com as músicas duras, porém cômicas, "Lôraburra", "Retrato de um playboy" e "Lavagem cerebral". Em 1995 lançou mais um álbum com as músicas "Estou errado" e "FDP" causando polêmica sobre as questões abordadas. Volta a fazer sucesso em $1997 \mathrm{com}$ as músicas "2345meia78, do disco "Quebra cabeça". Lança o disco "Nádegas a Declarar" em 1999. Em 2001 compôs um disco com as músicas "Seja você mesmo, mas não seja sempre o mesmo", "Se liga aí", "Até quando" e "Tem alguém aí". Em CD e DVD, lançou em 2003 o show MTV ao vivo com seus maiores sucessos. "Cavaleiro andante" é lançado em 2005 e o álbum "Sem crise" de 2012, fala sobre si, conta suas experiências e paixões.

Gabriel casou-se com a cantora e atriz Ana Lima em 1999 e, junto com ela teve dois filhos, Tom em 2002 e Davi em 2005 e, depois de dez anos de união, o casamento foi encerrado. Além de cantor e compositor, Gabriel é palestrante e fala sobre educação, liderança e motivação. E também é escritor, lançou em 2010 o livro autobiográfico "Diário noturno". Quatro anos mais tarde lançou "Um garoto chamado Roberto", que ganhou o prêmio de melhor livro infantil. Ainda lançou o livro "Meu pequeno rubro negro" e, com a parceria da escritora Laura Malin escreveu "Nada demais". Gabriel ainda é ativista social, sendo patrono de vários projetos, como os de incentivo a profissionalização através do futebol, "Pensador futebol" e "Dream futebol" e o projeto "Pensando junto", que atende as crianças carentes da Rocinha.

A música "Astronauta" faz parte do álbum 'Nádegas a declarar' de 1999, ano em que o então presidente Fernando Henrique Cardoso, inicia seu segundo mandato. É instalada a CPI do Judiciário no Senado Federal, o Maníaco do Parque é condenado a 121 anos de prisão pela morte de dez mulheres no Parque do Estado, em São Paulo e o estudante Mateus da Costa Meira mata três pessoas na sala 5 do cinema no Morumbi Shopping, zona sula da capital paulista.

A violência, a política, a corrupção, a desigualdade social, a igreja, o racismo são alguns temas que Gabriel O Pensador com sátira, ironia, humor e metáforas utiliza em suas composições.

Analisando tematicamente a canção "Astronauta", ele critica o caos que se instalou na terra e adverte um astronauta que foi para o espaço, mas está empenhado em voltar para a terra, deixando evidente que se pudesse trocaria de lugar com ele para se livrar da correria do cotidiano, da desordem, da política da globalização e do desenvolvimento tecnológico que cresce de forma descontrolada que afeta de várias formas a vida do cidadão, principalmente das grandes cidades e acarreta aos poucos a exclusão dos mais pobres.

O rapper utiliza o engajamento social em sua composição, a letra da música passa uma mensagem bem clara sobre a situação do nosso planeta, principalmente sobre os problemas sociais que tornam cada vez mais desumanas as condições de vida dos indivíduos, seu descontentamento ganha forças quando ele demonstra uma conversa com o astronauta, como se percebe a seguir pelo autor Gabriel, $O$ Pensador (1999)

Astronauta tá sentindo
falta da Terra?
Que falta essa Terra te
faz?
A gente aqui embaixo
continua em guerra
Olhando ai pra lua
implorando por paz Então
me diz: por que você quer
voltar?
Você não tá feliz onde
você está? Observando
tudo à distância
Vendo como a Terra é
pequenininha
Como é grande a nossa
ignorância
E como a nossa vida é
mesquinha
A gente aqui no bagaço,
morrendo de cansaço
De tanto lutar por algum
espaço
E você, como todo esse
espaço na mão Querendo
voltar aqui pro chão?!
Ah não, meu irmão... qual
é a tua? Que bicho te
mordeu aí na lua?

Percebe-se como o compositor trabalha com certa ironia e sarcasmo e questiona em sua 
composição qual a falta que esta terra desigual e com tantos problemas pode fazer falta ao astronauta. São perguntas que ele mesmo responde, demonstrando as dificuldades que o homem enfrenta no seu cotidiano, dando assim, razões para o astronauta permanecer onde está.

Apresentando a teoria literária empregada por Gabriel, Bakhtin (apud MACHADO 1995, p. 41) dá conta de esclarecer tal empregabilidade, quando assim se pronuncia: Heteroglóssia ou mistura de diferentes grupos de linguagens, classes $e$ culturas, foi formulado por Bakhtin para apreender o movimento contínuo da língua, impedindo hegemonia de uma linguagem única. Heteroglóssia só existe onde houver diferentes pontos de visão, ou diferentes sistemas de interação. Por exemplo: autor/personagem, eu/outro, monólogo/diálogo, cânone/carnavalidade, oralidade/escrita.

Gabriel ser apropria deste conceito bakhtiniano quando mescla no excerto anterior, oralidade e escrita - "astronauta, tá sentido falta da terra" - ambientadas na sua composição musical, em convivência harmoniosa. São linguagens que não se excluem, melhor dizendo, completam-se. Em muitos outros fragmentos a oralidade é a marca registrada no interstício da linguagem culta que este compositor pratica.

No excerto a seguir, ele (GABRIEL O PENSADOR, 1999) reitera como a vida fora da terra é prazerosa e de como muitas vezes as pessoas necessitam de paz interior.

Eu vou pro mundo da lua Que é feito um motel Aonde os deuses e deusas Se abraçam e beijam no céu

O compositor apresenta a crença humana da salvação como oriunda de poderes divinos, traz à tona a fé humana, demonstrando alguns problemas sociais. Novamente pode-se observar que ele pergunta e responde, não concedendo a voz ao Astronauta, enaltecendo as razões para que o mesmo se mantenha afastado das adversidades terrenas, como o poeta Gabriel, O Pensador (1999) pode mencionar:

Ah não, meu irmão... qual

é a tua?

Que bicho te mordeu aí

na lua?

Fica por aí que é o melhor que você faz

A vida por aqui tá difícil demais

Aqui no mundo, o negócio tá feio

Tá todo mundo feito cego em tiroteio

Olhando pro alto, procurando a salvação

Ou pelo menos uma

orientação

Você já tá perto de Deus, astronauta

Então, me promete Que pergunta pra ele as respostas

De todas as perguntas e me manda pela internet

Neste fragmento, o eu lírico aparece dialogar com o ser humano "Astronauta", revela que o ser humano cada vez mais se vê à mercê da tecnologia. Como este talvez esteja próximo de Deus, aquele pede que as respostas para todas as perguntas venham prontas do Divino e cheguem ao destinatário pela Internet. É o desenvolvimento tecnológico tomando conta da vida do cidadão, como referenda o mencionado autor (1999)

É tanto progresso que eu pareço criança

Essa vida de internauta me cansa

Astronauta, você volta e me deixa dar uma volta na nave,

Passa a chave que eu estou de mudança

Seja bem-vindo, faça o favor

E toma conta do meu computador

Porque eu tô de mala pronta, tô de partida E a passagem é só de ida Tô preparado pra decolagem, vou seguir viagem, vou me desconectar Porque eu tô de saco cheio 
E não quero receber nenhum e-mail dessa merda de lugar

Gabriel O Pensador conhecido por denunciar a situação social do país, com suas letras em tom de ironia e indignação, também faz referência ao relacionamento humano, explicitando como as pessoas vivem em sociedade. Sobre tal condição de vida conturbada, o autor (GABRIEL O PENSADOR, 1999) assim se pronuncia:

Eu vou pra longe, onde não exista gravidade Pra me livrar do peso da responsabilidade De viver nesse planeta doente

E ter que achar a cura da cabeça e do coração da gente

Chega de loucura, chega de tortura

Talvez aí no espaço eu ache alguma criatura inteligente

Aqui tem muita gente, mas eu encontro solidão Ódio, mentira, ambição Estrela por aí é o que não falta, astronauta A Terra é um planeta em extinção

É possível identificar em alguns trechos da música a linguagem coloquial, onde o autor procura interagir com as pessoas, quando dialoga com 0 astronauta. Os aspectos socioculturais estão intrinsecamente ligados à oralidade a qual influencia a escrita do eu lírico. Gabriel O Pensador utiliza esta linguagem no intuito de poder se aproximar de seu público, fazer com que haja uma identificação com a música. No que tange à oralidade deitada no papel como manifestação escrita, Marcushi (2001, p. 35) assim referencia:

A língua, seja na sua
oralidade falada ou
escrita, reflete, em boa
medida, a organização da
sociedade. Isso porque a
própria língua mantém
complexas relações com
as representações e as
formações sociais. Não se
trata de um
espelhamento, mas de
uma funcionalidade em

geral mais visível na fala. É por isso que podemos encontrar muitos correlatos entre variação sociolinguística e variação sociocultural.

O autor reitera a relevância tanto da oralidade quanto do letramento seja explicitada a partir das práticas de linguagem. Não se trata de uma relação oposta, mas sim situada em práticas sociais e históricas contínuas.

É possível encontrar o teor social contido em músicas e em composições literárias, ou seja, o quanto elas estão interessadas nos problemas sociais. Candido $(2006$, p. 83 ) sobre o valor artístico com tom sociológico menciona que:

O valor artístico, só de modo sociológico é possível elucidá-lo nas suas formas concretas particulares - pois nas sociedades civilizadas a criação é iminentemente relação entre grupos criadores e grupos receptores de vários tipos. Isto quer dizer que o escritor, numa determinada sociedade, é não apenas o indivíduo capaz de exprimir a sua originalidade (que determina e especifica entre todos) mas alguém desempenhando um papel social, ocupando uma posição relativa ao seu grupo profissional e correspondendo a certas expectativas do leitor ou auditor.

Os estilos literários e as canções populares tratam de duas composições diferentes, mas possuindo uma relação íntima, quase complementar. Os poemas com sua linguagem verbal envoltos de toda literalidade que eles guardam e esperam a atividade leitora da recepção para desvendar tais propriedades simbólicas; a letra de música que aglutina o jogo de elementos verbais acrescidos das composições harmônicas do campo musical. Segundo Bosi (1977, p.21), o fenômeno verbal é uma conquista na história, pois com a liberação dos órgãos da boca, utilizados até então para a 
alimentação, o homem, pode exercer mais eficazmente sua ação sobre o mundo externo".

Existe uma relação intertextual entre as poesias e a letra da música. A uniformidade entre as partes que compõem o texto, permitindo ao leitor uma conexão com o mundo ali apresentado e, a ligação que existe com a época em que foram escritas, revela do autor ao leitor, alguns dos valores de seu contexto histórico.

Pensando com Candido (2006, p. 85) "a obra não é produto fixo, unívoco ante qualquer público, nem este é passivo, homogêneo, registrando uniformemente seu efeito". O autor propõe que a literatura é um dos meios pelo qual o indivíduo entra em contatos com realidades que podem parecer distantes de seu mundo e que, a literatura pode ser considerada uma forma de conhecimento da realidade social e humana.

Por haver uma aproximação entre literatura, música e história, o compositor brasileiro contemporâneo reproduz algo já escrito em face aos estilos literários, o autor utiliza alguns recursos próximos ao do poeta. A música por ser destinada ao ouvinte, e é este quem diz o ritmo de sua recepção, o compositor de música utiliza uma linguagem mais direta, com repetições (refrão) próximas a linearidade do som. "Quando se lida com a música o termo "ritmo" se reporta a um momento uniforme de produção sonora" (BOSI, 1977, p.68), e o autor ainda ressalta "os ritmos poéticos nascem na linguagem do corpo, na dança dos sons, nas modulações da fala". (BOSI, 1977, p.68).

As manifestações culturais são originárias tanto do campo literário, quanto do musical. Desde o Romantismo até o Modernismo, a poesia brasileira da primeira geração, o pessimismo da segunda geração e a terceira geração com sua poesia social, humanista, preocupa com a abolição dos negros, a independência dos povos, o fim da miséria e com a educação, como forma de transformação, e qualidade de vida do ser humano.

Na modernidade, a música é uma forma de manifestação cultural diversa. Quando se assemelham aos textos que a precedem tornamse uma paródia, pois há uma identificação, quando se apercebe que desde José Saramago que busca no livro "Os Lusíadas" de Luís de Camões, para escrever "A fala do velho do restelo ao astronauta", até Gabriel O Pensador que têm ao seu alcance uma vasta gama de obras para contextualizar e as utilizas em suas composições, como na música "Astronauta".

Como a música desperta o interesse das pessoas, é porque os campos harmônicos são recebidos e computados pela área do cérebro que trabalha as emoções. Atividades relacionadas à música, tendem a se tornar um exercício prazeroso e eficiente ao dividir os próprios impulsos harmônicos com outrem. No que diz respeito à produção textual, propostas voltadas à composição de letras musicais oferecem a possibilidade de amplitude de vocabulário, estruturação do pensamento lógico, objetivo e claro. Trata-se então de uma forma prazerosa de propiciar o contato com o universo escrito.

A música surge como alternativa para torna o processo de leitura mais instigante pelo fato de essa manifestação cultural já estar inserida no universo e no cotidiano do aluno, e as novas tecnologias facilitam o acesso do aluno a essa manifestação. Partindo desse pressuposto, a escolha do gênero musical, passa a ser um instrumento pelo qual o professor possa dispor nas aulas de leitura, pois não é difícil atrair o aluno para este gênero devido a sua popularidade, diferente de se utilizar somente textos para exemplificar a leitura. Afinal, é muito fácil gostar de música e, dificilmente será encontrado alguém que não aprecie uma canção.

\section{REFERÊNCIAS}

BAKHTIN, M. Questões de literatura e de estética. São Paulo: Hucitec, 1988.

BOSI, A. O ser e o tempo da poesia: a imagem e o tempo da palavra. São Paulo: Cultrix, 1977.

CANDIDO, A. Literatura e sociedade: $O$ escritor e o público. 9.ed. Rio de Janeiro: Ouro sobre Azul, 2006.

FONSECA, J. J. S. Metodologia da pesquisa científica. Fortaleza: UEC, 2002.

MACHADO, I. O romance e a voz: prosaica dialógica de M. Bakhtin. Rio de Janeiro: Imago. São Paulo: FAPESP, 1995.

MARCUSCHI, L. A. Da fala para a escrita: atividade de retextualização. São Paulo: Cortez, 2001. 
MOISÉS, M. A literatura portuguesa. São Paulo: Cultrix, 1997.

NASCIMENTO, G. M. S. Letras da música popular brasileira como recurso didáticometodológico alternativo para o ensino de física: Perspectivas atuais e sugestões para implementação em aulas do ensino médio. Monografia (Graduação em Física) - Universidade Federal Fluminense. Niterói, 2012. Disponível em: <http://www.ensinodefisica.net/Materiais/mon ografias/monogeisa.pdf $>$. Acesso em: $10 \mathrm{dez}$. 2017.

SARAMAGO, J. Os poemas possíveis. 1. ed, Lisboa: Porto Editora, 2014.

Recebido para avaliação: 05/09/2018

Revisado em: 25/10/2018

Aceite Final: 13/11/2018 